\title{
Ubuntu is homeless: An urban theological reflection
}

\author{
Author: \\ Stephan F. de Beer ${ }^{1}$ \\ Affiliation: \\ ${ }^{1}$ Centre for Contextual \\ Ministry, University of \\ Pretoria, South Africa \\ Correspondence to: \\ Stephan de Beer \\ Email: \\ stephan.debeer@up.ac.za

\section{Postal address:} \\ Centre for Contextual \\ Ministry, University of \\ Pretoria, Pretoria 0002, \\ South Africa \\ Dates: \\ Received: 12 May 2015 \\ Accepted: 07 July 2015 \\ Published: 28 Sept. 2015 \\ How to cite this article: \\ De Beer, S.F., 2015, 'Ubuntu \\ is homeless: An urban \\ theological reflection', \\ Verbum et Ecclesia 36(2), \\ Art. \#1471, 12 pages. \\ http://dx.doi.org/10.4102/ \\ ve.v36i2.1471 \\ Note: \\ Research Participant in the \\ Ubuntu-Research project of \\ the University of Pretoria.

\section{Copyright:} \\ (C) 2015. The Authors. \\ Licensee: AOSIS \\ OpenJournals. This work is \\ licensed under the Creative \\ Commons Attribution \\ License.
}

\section{Read online:}

Scan this QR code with your smart phone or mobile device to read online.
This article is reading ubuntu in the light of homelessness in the cities and towns of South Africa. It suggests that $u b u n t u$ itself is homeless and displaced as a way of being human together. Instead of the mediation of dignity and justice through an ubuntu-solidarity, street homeless people and others living vulnerably and in precarious circumstances are violated and excluded through a displacement of $u b u n t u$-values. It also suggests a growing disconnect between the philosophy of ubuntu and its actual embodiment in the local urban political economy, local faith communities and local universities. Acknowledging the aspirational edge of $u$ buntu, the article then concludes to envision going beyond mere abstractions in the said spheres - the political economy, faith communities and local universities - in order to seek for concrete expressions of $u b u n t u$-solidarity, asserting and mediating respect, dignity and justice.

\section{Ubuntu: Reality, rhetoric or illusion?}

There is a current fascination, almost preoccupation, amongst intellectuals with the term $u b u n t u$, and a cooptation amongst politicians, particularly those of a populist nature, of the same term:

- Perhaps, sometimes, it is a symptom of the Africanisation project that (post)-colonial universities are embarking upon, even if only artificially, and having a term like ubuntu to trade with becomes helpful.

- Perhaps, for others, ubuntu is a useful term to hide selfish greed and convenient forgetfulness of the poor behind, suggesting, even falsely, a faithfulness to former values of communal solidarity.

- For some it could indeed be a search to return to lost roots, either romantically for brief moments of reflection, or more radically in terms of reversal of lifestyles.

- There might be some that truly yearn to retrieve communal values seemingly embodied in ubuntu, as a way to help reclaim our lost humanity.

However, the genius of Biko's foresight is evident in these words, which at the same time serves as a tool to unmask the illusion of ubuntu-rhetoric (Biko 2008):

This is one country where it will be possible to create a capitalist black society ... And that capitalist black society, black middle class, would be very effective ... South Africa could succeed in putting across to the world a pretty convincing, integrated picture, with still seventy percent of the population being underdogs. (pp. 41-42)

What Biko described and even feared is exactly what happened: an emerging black middle class and elite, co-existing with white capital, but $70 \%$ of the population are still underdogs. Nigel Gibson in his analysis of post-apartheid South Africa contrasts Biko's black consciousness of solidarity, particularly with the struggling poor, with what he calls a 'neoliberal corporate Black consciousness, which has become synonymous with making fast money and treating your brother as a purse' (Gibson 2011:69). Gibson (2011:83) suggests that Mbeki's African Renaissance cloaked its neoliberal approach and business model with $u b u n t u$-rhetoric, although there is an increasing lack of evidence of $u b u n t u$-practices or lifestyles, both personally and politically.

Soja (2000:216) speaks of neoliberalism as 'increasing privatization of the public sphere', 'attacks on the welfare state and labor unions', and promoting 'the magic of the market, the ineffectiveness of Big Government, the triumph of capitalism'. Neoliberalism - evident in the urban political economy, the privatisation and commodification of religion, and the transformation of the university - is consistently at odds with the ethical imaginations of ubuntu-values, and daily perpetuating the violation and marginalisation of those who are particularly vulnerable in society, including those who live precariously on the streets.

This article would like to consider $u b u n t u$ in the mirror of homelessness on the streets of South Africa's cities and towns. The sheer vulnerability and risk faced by those living their lives on 
the streets for however brief or long - women and men, children and the elderly, people living with chronic mental or physical illness - raises immediate questions as to the reality of $u b u n t u$, or the lack thereof: our common and caring humanity, our deep interconnectedness.

I would further like to suggest that $u b u n t u$ itself, at least in the context of considering homelessness in urban South Africa, is not just vulnerable but homeless, displaced, long replaced as a way of life, a way of being, a way of being human together. I also suggest that there is a deep and growing disconnect between $u b u n t u$, if and where practised, and ubuntu peddled as the African way in rhetoric and remote philosophical discourse.

Hankela (2013:324) speaks of a similar disconnect between the ubuntu-discourse of philosophers, politicians and marketers alike, on the one hand, and the reality of foreigners being killed, homeless people being ostracised, and socioeconomic disparities continuously growing, on the other hand. And yet, at the same time, it proposes that at the very moment of recognising the displacement of ubuntu - in the circle of the homeless poor and the displaced refugees opportunities for a recovery of ubuntu as community, humanity and humanness, in local contexts, together, will appear.

I understand $u b u n t u$ in the sense of humanity, humanness and interdependence, and use the concept as both an inclusionary and aspirational ethic: inclusionary in the sense of envisioning and practising a radically inclusive community, informed by liberation theology's solidarity with the poor (cf. the vision of Verryn below); and aspirational in the sense of its permanent attempts to be embodied concretely in personal, communal and socio-political relationships. I argue for the recovery of an ubuntu, precisely in the face of and in solidarity with homeless communities, and, in a different sense, in acknowledgement of our universal longing to be 'at home'.

\section{Homelessness and ubuntu}

Homelessness lacks a single definition that is able to capture the complexities of the phenomenon. Generally speaking, however, homelessness would refer to displacement, extreme forms of vulnerability, disenfranchisement, and the lack of access to sustainable sources of livelihood, whether shelter, employment, sanitation, social networks or education (cf. Cross et al. 2010:5-8)

Quite literally it refers to the lack of 'home', or shelter, or defensible life space, but 'home' in itself probably refers to more than physical structure. It also evokes various other categories such as belonging, security, caring, ownership, agency, nurture, sources of livelihood, family. Being 'homeless', indeed means lacking physical shelter as well as the other elements that constitute home, or the ability to live well.
Research done by the Human Sciences Research Council (HSRC) (Cross et al. 2010:7) on street homeless people in South Africa, estimated a number of 200000 homeless people living on the streets of our cities and towns. In their definition they focused on people living on the streets without any form of shelter, thereby excluding the continuous proliferation of millions of people living in informal settlements or inner city slum buildings across the country. Those living in informal settlements further illustrate how millions of South Africans live in precarious conditions. Vellem (2014:207), with reference to Anton Harber, speaks of 182 informal settlements in the city of Johannesburg alone, and close to 2000 informal settlements existing in the whole of South Africa.

The face of homelessness since the early 1990s has changed substantially in South Africa, in both diversity and complexity. Increasingly the youth, women, people with chronic mental illness and foreign migrants are amongst those who are homeless. Although the majority of homeless people in South Africa is black, homelessness knows no race, age, gender or nationality, even if government policy, and various government and non-government interventions and services show prejudice and favour in who they serve and who not. There seems to be an eternal quest for who is 'truly homeless' in order to restrict services by fine-tuning criteria for inclusion. This seems to be the case with both government and some non-government agencies.

The depth of vulnerability of people living with chronic mental illness on the streets, or of the frail elderly unable to help themselves, of children and child-headed households, of girl children and refugee families should evoke in us the depths of compassion and generosity. And yet, society responds with numbness and apathy, greed and personal self-enrichment; and instead of generosity aimed at inclusion, administering justice for all, and asserting our common humanity, the services provided and the municipal plans being executed often marginalise people even further.

In the now famous Grootboom case, Albie Sachs (2009) said the following:

The right of access to adequate housing would have no meaning if a thousand people ... were left without a place to lay their heads and without even minimal shelter, only a spot on a dusty ground and a few pieces of protective plastic sheeting. (p. 177)

And yet, the reality in the City of Tshwane, for example, is that more than 5000 people are street homeless people (Van Zuydam 2014), 'without a place to lay their heads and without even minimal shelter'. Does this then indeed mean that the right of access to adequate housing, inscribed in the Constitution of the Republic of South Africa, has no meaning, neither for the people who lack access to housing nor for the local government on which streets they find themselves at night, nor for their fellow citizens whose humanity is deeply intertwined with the lives of street homeless people? 
If the right of access to adequate housing was indeed embraced and considered seriously, then local government would have invested substantially in both physical infrastructure and services mediating alternatives to street homelessness; private sector and social housing institutions would have designed and created innovative housing solutions to give expression to this constitutional right; and fellow citizens, either denying the presence of street homelessness in their neighbourhoods, or responding through short-term charity and relief projects, would have understood that the lack of access to affordable housing and sustainable jobs, and the segregated neighbourhoods still being perpetuated in South African cities, both racially and economically, are unsustainable in the long term and potentially bearing severe consequences for all neighbours and citizens in the city. They would have embraced street homeless people as neighbours, sisters, brothers and fellow citizens, who need to be included in the design of integrated, mixed-income and mixed-use neighbourhoods, that are well-managed, in the interest of all the inhabitants of the city.

Cornell, Van Marle and Sachs (2014:30), with reference to the Grootboom case, state that the decision of the court recognised, 'that the desperate situation of the totally homeless is a form of violence that can undermine an individual human being's dignity to the point that it makes a mockery of the very ideal of dignity'.

The South African constitution holds dignity both as an ideal and as a right, and therefore the reality of street homeless people in the cities and towns of South Africa should be seen as a violation of their dignity and an insult to this ideal of the constitution as well as a recognition that ubuntu-solidarity has been replaced with exclusion and violation.

Justice Albie Sachs (2005:para. 37), for example, retrieves ubuntu-principles in considering the ways in which the law is interpreted and practised, particularly in relation to issues of landlessness, homelessness and spatial injustices in cities and towns. He interprets the PIE $A c t^{1}$ by evoking the spirit of ubuntu. He (2005:para. 37) suggests that the spirit of ubuntu 'suffuses the whole constitutional order' and therefore, in considering PIE, courts should 'infuse elements of grace and compassion into the formal structures of law'.

In cases of competing interests, argues Sachs, the rights of both land owners as well as of those who occupied land in a desperate bid to secure housing, need to be balanced. The PIE springs from a 'vision of a caring society based on good neighbourliness and shared concern' (cf. Sachs 2005:para. 37). Cornell and Muvangua (2012:18), in reference to the PIE and Sachs' interpretation thereof, suggest that ubuntu is institutionalised both ethically and socio-politically in this act. However, the fact that local and provincial governments act regardless of the act and in breach of the act, is not only a displacement of the people made vulnerable in the process, but of ubuntu itself.

1.Prevention of Illegal Eviction Act, 1998.
Failure of $u b u n t u$, or failure of people to live by the values, implicit and explicit to ubuntu, suggests displacement of ubuntu: the reality of street homelessness, informal settlements and other forms of precarious living, suggests that $u b u n t u$ as a way of being human together has probably been replaced by greater individualism and privatisation, isolating the poor from the rich and excluding them from access to resources of decent living and sustainable livelihoods. Of course, it would be mistaken to suggest that such an ideal ubuntu-society existed at one stage, particularly in South African cities. What would be fairer to say is that the segregated nature of South African cities, perpetuated by apartheid, is continuing in post-apartheid South Africa through new forms of segregation and the perpetuation of the old apartheid city structure. In addition, the frail fabric of urban society, with the extended family not holding up as has traditionally been the case, giving rise to a growing number of elderly homeless people, and with rural-urban migration increasingly evident in South African cities, often replacing communal livelihoods and support systems with individualised attempts to survive, means that the ethos of ubuntu is seldom evident in the fractures of the city where street homelessness is rife.

\section{Meaning(s) of ubuntu?}

Ubuntu is a Nguni word speaking of humanness/humanity (Hankela 2013:1). In the past decades the proverb 'Umuntu ngumuntu abantu' ('a person is a person because of others') was popularised as one way to interpret and understand ubuntu: what I do affects others; if one person is violated the whole community suffers; if I fail to act a whole community might be affected detrimentally (cf. Hankela 2013:1-2).

Desmond Tutu (in Hankela 2013) describes ubuntu as follows:

We are bound up in a delicate network of interdependence because ... a person is a person through other persons. To dehumanize another inexorably means that one is dehumanized as well. (p. 35)

Although the roots of $u b u n t u$, at least etymologically, lie in Africa, Shutte asserts that 'the values that it contains are not just African. They are values of humanity as such, and so universal' (Hankela 2013:39; Shutte 2001:2). That is also why some of the most creative and critical dialogue takes place when $u b u n t u$ is brought into creative and critical dialogue with other systems of thought (cf. Hankela 2013:38), be it jurisprudence, theology, development studies, or city planning.

An ubuntu-discourse presents us, according to Hankela (2013:2), with an ethic 'that treasure a set of relational qualities', such as openness to others, sharing, care, hospitality and respect (Hankela 2013:4), contributing to 'certain kinds of human relationships that reflect interdependence in community'. It is however not an abstract concept only but is actualised in concrete relationships; in being human together we become human (cf. Hankela 2013:4). 
Cornell et al. (2014:23) echo this, suggesting that ubuntu has an 'aspirational edge' to it, as there is no end to the struggle for a more humane world in which we at the same time become more human in relation to other humans. There is an 'activism inherent in the notion of an ethical relation to the other' continuously calling us to engage.

The aspirational aspect of the word requires of us to go beyond abstractions in our use of ubuntu (cf. Cornell et al. 2014:24), or abstract respect for the dignity of others, in order to seek for concrete expressions of the public good that will assert dignity and respect concretely in the ways in which people's humanity and well-being is enhanced. Mkhize (Hankela 2013) puts it well, saying:

Ubuntu requires that ethics be reconceptualized. An African approach to ethics is not concerned with principles that have been abstracted from their social contexts. (p. 297)

In reflecting on the building of a constitutional democracy in South Africa, Judge Jajbhay (2007) asserts that the values of ubuntu must play a fundamental role. He defines ubuntu in the following way:

Ubuntu is a culture which places some emphasis on the commonality and on the interdependence of the members of the community. It recognizes a person's status as a human being, entitled to unconditional respect, dignity, value and acceptance from the members of the community that such a person may be a part of. (para. 63-64)

It is important to note however that ubuntu does not exclude notions of individual identity or personhood even if it holds that our individual identities are very much related to and dependent on our corporate identity or belonging or interconnectedness. Saunders argues that the concept should not be reduced to interdependence at the expense of individual identity. However, it does consider personhood, and becoming a person, as an ethical journey with others.

Mokgoro (1995:paras. 306-308; cf. Cornell \& Muvangua 2012:8) also connects ubuntu and the building of democracy, referring to a distinction made by Carew between liberal democracy, which often holds self-interest and the market as the highest goods, versus deliberative democracy that emphasises dialogue and mutual respect as the basis for negotiating the public good. Ubuntu as a discourse moralises social relations (Cornell \& Muvangua 2012:8), suggesting that morality is not merely individual choices or personal preferences but should be considered in terms of its socio-economic-political and environmental implications.

Through a deliberative democracy that fosters mutual respect and dialogue, personhood can be formed, an ethical way of being together can be discovered, and the public good can be advanced. If homelessness means diminished personhood through radical forms of exclusion, violation of human dignity and lack of respect, and if it also means a substantial number of people in society being excluded from the public good, both are in fact suggesting the absence of $u b u n t u$ which finds expression in a depletion of humanness, personhood and morality. Homelessness then is about an immoral society; the radical embrace and practice of $u b u n t u$ in all spheres of life, or ubuntu as an African expression of radical Christian community, is what could recover humanness, personhood and morality.

An important point made by Cornell and Muvangua (2012:8-9), in their reflection on Mokgoro and More, is that respect for the other is not something that should be deserved or that can be lost, as it is rooted in the inherent dignity and equal worth of every human being. This should not be affected by being in an extremely vulnerable position, they further suggest, which could also apply to the extreme vulnerability of street homeless people or people precariously housed in slum buildings or urban informal settlements. Ubuntu-principles will respect human beings finding themselves in such precarious conditions, based on their inherent dignity and worth as human beings, and would seek to practise dialogue in order to negotiate ethical ways of overcoming their vulnerability, in the process affirming and enhancing their own personhood.

It is however, not only a philosophical, moral or ethical concept. Mabogo More (2006:149, 156-157) describes ubuntu as both an ethical or moral concept as well as a politicoideological concept. As a moral concept it seeks to guide practices that will enhance human well-being.

It enjoins that what is morally good is what brings dignity, respect, contentment and prosperity to others, self and the community at large. Ubuntu is a demand of respect for persons no matter what their circumstances might be.

As a politico-ideological concept, '[i]t enjoins and makes for peace and social harmony by encouraging the practices of sharing in all forms of communal existence'.

More's definition (2006:149, 156-157) enlarges an understanding of $u b u n t u$ beyond interpersonal relationships between human beings and places it as a guiding principle 'for all forms of social and political relationships', seeking for ways in which to express humanness, humanity or morality.

The ways in which communities will share material and economic wealth, include strangers in the city, and invest in the eradication of poverty, will be a reflection of the depth of ubuntu-values being practised, or not. Judge Jajbhay (2007) says:

uBUntu speaks to our interconnectedness, our common humanity and the responsibility to each that flows from our connection. This in turn must be interpreted to mean that in the establishment of our constitutional values we must now allow urbanization and the accumulation of wealth and material possessions to rob us of our warmth, hospitality and genuine interests in each other as human beings. (paras. 63-64) 


\section{The homelessness of ubuntu in different spheres}

If we are to retain a vision of ubuntu, we need to first acknowledge that ubuntu, at least in urban South African contexts, indeed seems to be homeless, in other words, displaced from the daily practices that deny ordinary people their humanness. For those of us seeking to do theology in cities of grave disparity, at that point of sober embrace of the displacement of a vision that some of us might hold dear, might then emerge a contextual $u b u n t u$-vision, informed, in a theological sense at least, by a liberationist understanding of Jesus.

At the point of discovering that ubuntu is homeless, we might also make a second discovery, namely of ubuntu in the homeless and the issues of homelessness, through our engagement with grass-root communities, helping us to grapple with 'the socio-moral meanings attached to being human(e) in particular 21st century contexts' (Hankela 2013:324). Hankela suggests that the question of ubuntu is the question of how we can live together as a human family in the midst of clear contradictions, socio-economically and otherwise (cf. Hankela 2013:324). In new-found solidarities we might indeed recover traces of ubuntu, humanness/ humanity, interrelatedness, interdependence, without which the lack of interdependence and common humanity will remain.

\section{Ubuntu and the political economy: National and local expressions}

The assertion of this section is that it does not take a philosophical treatise to see that $u b u n t u$ is largely displaced in practical urban politics and in the economic forces dictating political decision-making, even though ubuntu-rhetoric is often evoked.

Post-apartheid society has created the type of liberation that Biko would have abhorred: an artificial integration where a black middle class vies advancement in terms of a shrewd mixing of ' $u b u n t u$ ' rhetoric with possessive individualism (Gibson 2011:63).

Marx (2002:49; cf. Hankela 2013:42) critiques the cooption of ubuntu as a term by the political elite, saying 'a new cultural nationalism, centered on the notion of "Ubuntu", is preparing the ground in which the "flowers of evil" might once again blossom in South Africa'. He speaks of the gravest possible danger, if ubuntu is coopted as a term not of a liberatory humanity but rather of an exclusivist cultural nationalism, accompanied by 'possessive individualism'. This in fact goes against the very grain of $u b u n t u$-values.

It is indeed a question of whether a post-apartheid political economy has uttered the right rhetoric but in actuality engaged in practices that sold out the poor. Gibson (2011:63) reflects on Fanon's Wretched of the earth, suggesting that it was written to address the vacuum that existed within the anti-colonial movement 'about how to put a working, humanist programme into practice'. This vacuum, says Gibson, was a greater threat in the eyes of Fanon than the threat of the colonial regime itself. It could indeed be submitted that putting such a 'working, humanist programme into practice' might be an ongoing failure of a South Africa in transition.

The prevalence and ever-increasing reality of homelessness, landlessness and sprawling informal settlements, as well as the continuously growing disparities, seem to signal failure in this regard. Gibson (2011:63) speaks of the South African political transition as 'a revolution without a revolution', contained and determined by white capital both local and multinational (cf. Gibson 2011:63-64). Terreblanche (2012) describes this poignantly in his work, demonstrating how black political power and white capital colluded in ways that deepened socio-economic inequalities in South Africa post-1994.

The political economy post-1994 broadened the playing fields for capitalist interest in accumulating personal wealth but this at the expense of the well-being, dignity and humanity of the society as a whole. It is a neoliberal capitalism that was embraced by the state, denying our interconnectedness as human beings as well as the obligations that flow from such interconnectedness (cf. Cornell \& Muvangua 2012).

Do ubuntu-values have anything to offer with regard to the political economy, and how it plays itself out not only nationally but also in local communities and in the very way in which our cities and towns are structured? Is it an impotent philosophical concept, or indeed a useful ethical concept that could enable a different way of being, together?

It is the assertion of Cornell and Muvangua (2012) - with reference to More, Sachs and others - that ubuntu-values lived are able to resist and subvert neoliberal values through holding a reflective mirror: a return to ubuntu-values will help unmask in how far society has succumbed to the dominant values of the market, or in how far we all have become complicit in denying others their humanity by inflating ours. It is a mirror to be used at different levels of society and by different institutions: faith-based institutions, local governments, universities and schools, neighbourhood organisations and local residents groups. In how far are we allowing the values of the market to deny some their humanity in order for a few to live profitable lives steeped in mentalities of scarcity?

Eze(2010:145-149,158,175;cf. Hankela 2013:43) acknowledges that some regard $u b u n t u$ 's current popularity as a reinvention by the political elite with little substance to guide policy at any level. But Eze himself disagrees, suggesting that the value of ubuntu-discourse lies in it being a historical discourse that is always unfolding in history, finding unique expression in different socio-historical contexts over time (Eze 2010:184-186; cf. Hankela 2013:44). More specifically, Hankela (2013:44) suggests that ubuntu 'be understood in the 
context of a particular community'. For her, ubuntu seems to be humanness being negotiated, discovered and practised together, in the context of a particular local community, and sometimes in the context of humanity/humanness being deeply threatened due to violent exclusions and extreme forms of vulnerability; but in such circumstances $u b u n t u$ has the potential to hold a reflective mirror.

More (2002:24), in reflecting on Nyerere, goes even further. He speaks of African socialism as 'an ethos of avoiding inequality and domination but fostering humility and hospitality (ubuntu)'. More suggests African socialism as practising and fostering $u b u n t u$, that is, humility, hospitality, solidarity and a deep sense of sharing, recognising our deep interconnectedness. Hankela (2013:49), in reference to Shutte (2001:13), contrasts African socialism with Western socialism and communism in so far as it is built on an ubuntuunderstanding of community in which the individual's personhood is significant and not mere reduction to a machine (Shutte 2001:13). This is an important assertion as it counters the critique often levelled against socialism and communism, namely the denial of the individual or individual personhood. Ubuntu refrains from such denial, valuing and acknowledging the becoming of the individual, but acknowledging too that such becoming does not happen in isolation but in relation to others and to the larger community that helps shape who I become.

The reality of homelessness and increasing inequalities places a magnifying glass on the failures of neoliberal capitalism to mediate equality and justice. The value of an individual but also the interdependence, and therefore value, of a society are violated. It indeed calls for the recovery of ubuntu-values in society, also and particularly in an economic sense. These values are currently displaced by the values, practices and policies of neoliberal capitalism. A recovery of $u b u n t u$-values, if radically considered and worked out as a political and socio-economic programme, will probably facilitate forms of African socialism not yet explored in local urban contexts in South Africa. This is probably what More (2002:24) means when he says that African socialism is practising and fostering ubuntu; but at the same time practising and fostering ubuntu consistently might give rise to uniquely African forms of socialism.

\section{Restructuring cities}

If there is one area in which the radical embodiment of ubuntu-values might seriously disturb the status quo, it is in the spatial structuring of our cities and towns. South African cities have not yet seen the radical spatial restructuring required to allow increased access to sustainable jobs, good schooling and affordable housing, in so-called 'areas of opportunity', and, in particular, in close proximity to each other. For ubuntu to be worked out spatially, the interconnections between economic opportunity and the provision of affordable and accessible housing in such areas of economic opportunity need to be understood, planned and prioritised for, and invested in generously, in imagining the reweaving of the city fabric. People are attracted to areas of opportunity to attain an income, but the low income levels compared with high transport costs and lack of access to affordable housing, then doom many to become the homeless (under)employed.

Currently high-level politicians, as well as the contents of the National Development Plan (National Planning Commission 2012:233-260) and the Draft Integrated Urban Development Framework (Ministry of Cooperative Governance and Traditional Affairs 2014:5-7, 10-11, 23), both mourn the lack of spatial transformation of cities and towns post-1994 and envision radical spatial restructuring and transformation. However, local municipalities, in rolling out housing, perpetuate apartheid urban spatiality by positioning lowcost housing in and adjacent to formerly black townships and selling off vacant and available public land, in areas of opportunity, to the highest bidder, often thereby reducing or eliminating the chances of providing affordable housing close to job opportunities.

Relationships of solidarity, or innovative models of economic sharing, are replaced by profit motifs that do not usually trickle down to the poor. In the City of Tshwane, 81 properties and 10 parcels of land are being sold on auction in May of 2015 (Mbanjwa 2015). In the process at least one of those parcels of land is occupied by 4000 people who have been given the right to be on the land by a court order, instructing the local municipality to find a way to integrate this population into the redevelopment of this parcel of land. Instead, under the pretence of auctioning off the land to secure funding for informal settlement upgrades, notably out of sight in areas previously allocated for black people only and thereby perpetuating apartheid city structures, the poor are once again marginalised.

A significant percentage of homeless people are economically active but the low wages they earn compared to high transport costs and unavailable affordable housing options leave them in precarious situations of becoming the working homeless. This became evident in very recent research on street homelessness in the City of Tshwane. New pockets of homelessness are appearing, especially in more affluent suburbs of the city. This is often characterised by people who are working as gardeners, domestic workers or builders, but opting to stay in bushes or city parks, because of the disconnect between their actual income on the one hand, and the restrictive nature of public transport costs as well as lack of access to affordable housing in the vicinity, on the other hand (cf. De Beer 2015a).

The obligations flowing from a deep interconnectedness as human beings will include the ways in which we structure the urban spatial landscape to address issues such as these.

\section{Remodelling economic sharing: The gift of informality}

Restructuring cities will in itself facilitate remodelled economic sharing. Poorer people will be enabled to live closer 
to economic hubs and areas of opportunity, economically but also socially and educationally. But ubuntu-values will also embrace the gift and power of informality in asserting agency, finding dignity, and contributing to the overall wellbeing of urban society.

The hierarchy of economic power regarding the formal as the epitome of success, at the expense of the informal, is problematic. It allows for individual accumulation of wealth to always supersede the collective; for big shopping malls hosting national franchises to kill small local entrepreneurs; and for entrepreneurial responses to grass-root challenges to not be rewarded and mainstreamed as part of the socioeconomic solution. In Operation Clean-Up, amongst other activities, the City of Tshwane is removing informal traders from the streets, thereby terminating their economic activity and livelihood, registering them on a database to be trained for jobs, and then leave them waiting for jobs never to appear.

Instead, ubuntu-values will assert the value of informality and will build upon the agency of people and strengthen rather than destroy their initiative. Ubuntu-values will break with rigid hierarchies and rather foster circular models of economic participation and sharing that are inclusive and complementary. This is evident, for example, in the recycling practices of the Zokkatam community in Cairo.

In an article on the immense contribution by informal garbage dwellers in Cairo, Egypt, I tried to demonstrate how attempts by the local municipality to formalise garbage collection in that city not only marginalised the informal garbage dwellers, but had hugely detrimental effects on waste management in Cairo (De Beer 2014a). In fact, it was made clear by various scholars and practitioners reflecting on the case study of the Zokkatam community in Cairo that sophisticated corporate structures were simply unable to match the contribution these informal garbage dwellers could make through their collective actions and models of economic sharing.

In the City of Tshwane there is a substantial community of waste collectors, pushing their trolleys all over the city on a daily basis, often for miles at a time. They are informal workers and do not control the recycling depots where they sell the waste they collect. They are often treated with disrespect and disdain even by other users of the streets and pavements, and even criminalised at times.

In a conversation with the Regional Executive Director of one of the regions in the city, where trolley pushers are becoming a growing phenomenon, he was very vocal about the necessity of decriminalising this sector, rather integrating them fully into the city's economy, valuing the unmistaken contribution they make to the city in terms of effective waste collection and recycling. He hopes that cooperatives can be designed, developed and owned by the recyclers, with recycling depots owned by them being based all over the city in close proximity to their places of concentration (cf. De Beer 2015b).
This will be a creative way of living ubuntu concretely in a city of great disparity: acknowledging our interdependence and complementarity and remodelling economic sharing in ways that break from death-dealing hierarchy through circles of hope.

\section{Overcoming homelessness: A politics of compassion, generosity and justice}

Homelessness in the capital city of South Africa is highlighting the limitations not of $u b u n t u$, but of absent or weak $u b u n t u$-practices and policies. After many years the City of Tshwane finally approved a Policy on Homelessness in May of 2013 (City of Tshwane 2013). However, no budget was tied to this policy and no strategy was developed to translate policy into action. In a very real way, therefore, this policy could be regarded as offensive rather than constructive, because it was unable to make any inroads into addressing the challenges of a growing homeless population.

It is a rather technocratic document instead of oozing with an ubuntu-ethic of common humanity and interdependence that will make bold investment into addressing homelessness a moral obligation, but also a concrete way of honouring our common humanity. In a theological sense, if one part of the body suffers then the whole body suffer. In trade unions the slogan, 'an injury to one is an injury to all', united the workers around their plight and rights. In a similar way homelessness can evoke such a resurgence of $u b u n t u$-values and practices, if ubuntu is considered as a concept that unfolds in concrete local communities, as we learn how to be human together.

It is evident that the face of homelessness in the City of Tshwane has changed in remarkable ways in the past twenty years, but one of the most significant changes of the homeless population is the growing number of foreign nationals, refugees or asylum-seekers, finding the street as their home. However, the Tshwane Homelessness Policy is not only silent on this growing group of people, but is intentionally excluding them, suggesting that other policies will address their needs. It does not clarify which policies and it is not clear whether such policies even exist.

The Tshwane Homelessness Policy states explicitly in its Policy Directive 1 that 'CoT shelters will not accommodate foreigners/illegal immigrants' (City of Tshwane 2013).

Ubuntu-discourse will acknowledge all inhabitants, including foreign Africans, as part of our extended or common humanity, as sisters and brothers of one large human family. The Tshwane Homelessness Policy's exclusion of foreign nationals places them outside of such an assertion. They do not belong in the same way. It is ironic, though, as any solutions for homelessness in the City of Tshwane will not be found unless clear policies and strategies are in place that will deal with the growing population of homeless people who are foreign nationals. This is consistent with failure at national policy level to give expression to the discourse 
of integration that fails the moment it is tested through exclusive housing subsidies and lack of access to a variety of other state-funding schemes.

A recent project launched to address homelessness in the City of Tshwane is arguing for a politics of compassion, generosity and justice (cf. De Beer 2014b), which, from one angle, could be seen as an affirmation of our common humanity and a call for practising $u b u n t u$-values in how we engage issues of homelessness as policy-makers and citizens in general.

\section{Ubuntu and local urban faith communities}

Local urban faith communities do not display a depth of ubuntu in how they are interconnected or interdependent; rather the contrary. In the inner city of Pretoria there is a church on almost every city block - in church buildings, schools, shop fronts and museums - but they often hardly speak to each other. Some churches open sprinklers on homeless people to chase them off their doorsteps. The deep economic rifts between wealthy suburban churches and churches in urban informal settlements and townships are mirrors of society at large. And yet, it is perhaps exactly in the fractures of the city, in the faces of the homeless refugees, or the displaced children, that we have an opportunity, not only to discover the presence of Jesus, but also how to become human together.

Albert Nolan (2006:41) makes the distinction between spiritualities shaped by Western individualism (finding self through independence and finding God in deeply personal ways) as opposed to spiritualities shaped by ubuntuvalues (finding self in relation to others and finding God together). It will be a mistake to assume that there is a direct correlation between more individualistic spiritualities and predominantly white churches, or communal spiritualities and predominantly black churches. In fact, we should rather ask, where are the churches today that practise radical $u b u n t u$-values, marked by interdependence, deep and concrete forms of sharing, radical hospitality expressed in welcome and embrace, and astounding examples of humanness towards each other and the stranger? Too often, the dominant discourses subscribed to are similar in church and in society - there is very little evidence of the alternative, prophetic community.

In the context of Central Methodist Mission in Johannesburg, the challenge of migrants and refugees on their doorstep prompted the then Bishop Paul Verryn to open the doors of the church, not just for worship, but also for accommodation. This brave and at times very controversial story is well documented in Sanctuary by journalist Christa Kuljian, and in 'Challenging $u b u n t u$ ', the doctoral dissertation of social ethicist, Elina Hankela. At times, more than 2000 people slept in the building at night, a building not designed for such a purpose, but Verryn maintained that it was better than to put people out on the dangerous streets of Johannesburg at night.
For Verryn, the radical situation - homeless refugees sleeping on the streets - required a radical response (Hankela 2013:168).

He grounded his response in a simple but radical theological assertion, as Hankela (2013) explains:

$[H]$ e argues that 'the church's origin is with the homeless', because the founder of the faith was born homeless, and therefore the church should recognize its explicit responsibility to the dispossessed. (p. 130)

In a society marked by socio-economic disparity and an ever growing number of people being homeless or living in informal settlements, Verryn's insistence is that the church should practise a preferential option for the poor. Everyone is made equally in God's image but some do not have the same opportunities to exercise their humanity and likeliness in God's image. In such a situation the church should then opt for the poor, in order to erase poverty from society (Hankela 2013:156-157).

In Verryn's understanding a human(e) society would prioritise the poor. Hankela (2013:135) refers to a conversation with Verryn in which he asks: If more than $48 \%$ of South Africa's population earn less than R800 per month, which is the case, how then can any other ethical issue be prioritised over the death-dealing poverty faced by its people?

The praxis of Verryn is described by Hankela (2013:121) as a contextual Christian ubuntu-vision informed by liberation theological thinking. It is consistent with the liberation theological insistence on orthopraxy in that Verryn holds that there is no dogma without ethics, and no ethics without practical ministry engaged in the concrete realities of people on the ground (Hankela 2013:130). Verryn's primary concern with evoking ubuntu is for what it can do, instead of being interested in a dogmatic definition (Hankela 2013:164).

Verryn's ubuntu-preaching did not so much intend to understand anthropology or to articulate a philosophy or be a theology, but rather it aimed at praxis. Verryn did not preach $u b u n t u$ as an African philosophy but as a contextual Christian socio-ethical vision (Hankela 2013:164).

The notion of a radically inclusive community is at the heart of Verryn's contextual Christian ubuntu-vision (cf. Hankela 2013):

[T] he actualization of one's dignity and potential is reflected in dealings with others, and the actualization of Ubuntu in community could be reflected in the way individuals were respected and their dignity and potential celebrated. (p. 161)

The church is a global community of communities, but to be radically re-imagined from below, in the language of liberation theology and of Verryn. Let me consider it for a moment theologically, ecclesiologically and socially. 
Theologically, an understanding of sin should not be considered in an individualised or personal sense only, but more specifically in relation to the consequences of our actions in relation to others, the broader community and creation at large (cf. Orobator 2008:63). Although Orobator does not name it ubuntu, his description of an African understanding of life relates to ubuntu. Orobator (2008:63) states that life 'embraces the world of the yet-to-be-born, the living, the living dead (ancestors), and all other categories of animal and plant life, as well as the world of nature'. Sin then, in relation to such an understanding of life, refers to '[ $w]$ hat diminishes, opposes, or destroys this life'. If life is seen as a shared reality, as a communal affair, then it relates closely to ubuntu, as interconnectedness, but in a broader sense than only an interconnected humanity; it now includes all of creation. Sin would be all that disturbs the harmony or interconnectedness - the ubuntu - amongst humans and between humans and creation at large.

When we recall that life is a shared reality and event in Africa, it makes sense to think of sin as the poisoning of the community's life blood (Orobator 2008:63).

An understanding of ecclesiology in a Trinitarian sense would be through 'concrete examples of sharing life in all its aspects' (Healey \& Sybertz 1996:133). Healey and Sybertz (1996:133) beautifully write about the small Christian communities that are living intensely the Trinitarian life of mutual love, cooperation, participation and reaching out to others in loving service'. They compare it to 'the bonding of the mother and child who are like the umbilical cord and strap in which the cord is wrapped'. These are communities with a human face, sharing a deep sense of communal values and personal relationships (cf. Healey \& Sybertz 1996:143), and lived radically will truly embody the new community of Christ.

However, in our cities and towns there is little evidence of such radically Trinitarian communities, expressing the church-together-from-below, the church overcoming social, economic and human barriers through becoming human together in Christ, a church practising radical ubuntu-values.

In reference to Paul Verryn, Hankela suggests that his radical ubuntu-vision was perhaps too radical for many members of his church, and indeed the church as an institution, to receive it. In fact, when Verryn's term as minister of Central Methodist Mission came to an end in December of 2014, the church indeed departed from Verryn's vision with almost immediate effect. The same space that had been home to refugees finding themselves in extremely precarious circumstances now became off limits to them and they were evicted from this space (Motumi 2014; Rahlaga 2014). A safe haven became a place of animosity. The church participates in displacing $u b u n t u /$ humanity/humanness from its midst in theological terms, perhaps much deeper, a Trinitarian communal understanding of church, more particularly, the presence of Jesus in the homeless stranger.
Verryn's radical vision of what ubuntu/humanity would mean in the context of inner city Johannesburg is rooted in 'who God is and where God calls humankind to be and become' (Hankela 2013:168). Verryn's vision is especially radical in its inclusiveness. In Verryn's reflections on humanity he refers to the 'inclusive humanity of Christ' and to 'the whole of humanity' as 'God's chosen people' (cf. Hankela 2013:147). His are not romantic or intellectual categories but seeking for radically concrete expressions thereof in how humanity in its most vulnerable forms is embraced and socio-economically-politically affirmed.

An ubuntu-vision of the church's social presence in and engagement with the city would be radical in its embrace of vulnerability and strangers. Verryn's opting for embrace is a conviction that it will affect liberation (Hankela 2013:145). Ubuntu is an embracing community, embracing the other, the stranger, the opponent, welcoming instead of pushing away, discerning ways of being human together in order to become.

In such a deep embrace, solidarity with the struggles of the homeless stranger and migrant poor will develop, because we belong to a common humanity, and ecclesiologically, to one family. Local churches and faith communities valuing ubuntu would come alongside what Gutierrez speaks of as the 'nonpersons' (Hankela 2013:143): to affirm personhood to those violated in a society where values of humanity and community are depleted (cf. Hankela 2013:138). This is what would truly set apart the local faith community: its deep identification with 'nonpersons' and its subversion of such violations of humanity through a deep embrace. It is about communal solidarity that contrasts individualist understandings of being human, expressed only in personal accomplishment often at the expense of mutuality (cf. Hankela 2013:146).

\section{Ubuntu and local universities}

A last sphere for reflection is that of ubuntu and local universities in the South African context. There is a great danger that higher educational institutions in South Africa may speak of ubuntu, fund research projects with ubuntu as research topic, even include the philosophy or ethics of ubuntu in mainstream curricula, but fail to embody ubuntuvalues institutionally and socially.

The challenges should be clear: a contemporary South African society in which $45.5 \%$ of the population live below the breadline; South African universities that increasingly accommodate trickles of students from that population; and homelessness being a reality both for some university students but also in the very neighbourhoods hosting universities and their dedicated research.

The question of the local university and ubuntu probably needs to be considered at three levels: its internal institutional culture; its curriculum, ways of knowledge production and educational outcomes; and its socio-economic impact on surrounding neighbourhoods. Can homelessness and 
solidarity with homeless people help transform the university in terms of its institutional culture, ways of knowledge production, and socio-economic impact on society? Can engagement with homelessness be a pathway mediating embodied $u b u n t u$-values, at least in some sectors of the university, whilst simultaneously the university's engagement with homelessness can mediate pathways out of homelessness for people facing 'living death' on a daily basis?

In terms of institutional culture it first needs to be questioned whether ubuntu-values, in the definition provided before, ever existed in universities. Universities have probably always been elitist institutions of academic advancement, by definition excluding those who cannot comply with the strict access criteria to participate in the academic endeavour, and more than that, preparing people mostly for positions in life that will take them away from places of poverty and vulnerability, in a quest for individual accumulation of wealth, prestige and power.

In contemporary South Africa the question of $u b u n t u$ and universities firstly has to be about the integrity of $u b u n t u-$ discourse on campuses and whether we in fact embody ubuntu-values ourselves. Without such critical self-reflection the discourse, and the amounts of time and funding devoted to it, seems like useless intellectual game-playing, void of real meaning.

In December 2014 a collaborative project was launched between the City of Tshwane, the Tshwane Homelessness Forum (a network of non-profit organisations and homeless people), the University of Pretoria and the University of South Africa, to combine efforts in a search for sustainable pathways out of homelessness (cf. De Beer 2014b). An intensive research project led to a Homeless Summit held on 25-26 May 2015, drawing more than 400 people into conversations that surfaced research outcomes, narratives of (former) homeless people, presentations of existing practices seeking to address homelessness, and reflections and recommendations on a proposed policy and strategy for the city regarding street homelessness.

In their opening addresses at the Homeless Summit, both Prof. Norman Duncan (2015), deputy-vice-chancellor: academic of the University of Pretoria, and Prof. Andrew Philips (2015), Director of the College of Humanities at the University of South Africa, made clear institutional commitments to this project, not only for the duration of the Summit but for long-term engagement, research and support. Having researchers and students around tables with homeless people, street activists and community practitioners, created new tables where diverse knowledge and experiences could be shared in ways that could potentially be transforming knowledge for the public common good (cf. De Beer 2014c:228-230).

Could an ongoing commitment in this space offer a small window for some academics and students to embrace a more inclusive scholarly practice that is indeed committed to social change and the inclusion of the most vulnerable? And could the mutuality found at such new tables help nurture, even if only in small quarters within academic institutions, ubuntuvalues and practices?

Similarly, ubuntu-discourse needs to ask critical questions of curriculum and educational outcomes. Curriculum and content that does not seriously consider and engage the contexts of the university, in deep solidarity with such contexts, understanding the interdependence and possible mutualities that can exist between them, simply pay lip service to any notions of ubuntu being advocated. If educational outcomes fail to instil deep values of humanity, humanness, solidarity, care, inclusivity and respect, but rather has the opposite effect, the educational outcomes need to be seriously reconsidered.

In reference to the Urban Studio of the Centre for Contextual Ministry at the University of Pretoria, that managed the research process for the Homeless Summit, I wrote the following paragraph which could equally be said of the Homeless Summit and the process it was embedded in (De Beer 2014c):

It is my assertion that such mutuality, from below and from within, could foster the kinds of knowledges that cities require: fostering an urban household from below, in which new kinds of belonging and new ways of knowing could help mediate new forms of justice and interconnectedness, more inclusive and more sustainable, because it is informed and owned by the people. (p. 230)

The deepest crisis of higher educational institutions in South Africa today is probably not shrinking government subsidies, equity amongst staff members, or even the quality of education students receive. The deepest crisis could be its lack of sustained, transformative engagement with surrounding communities or neighbourhoods hosting them. In this regard one could well ask in how far the presence of the university is contributing to the socio-economicpolitical transformation of its surrounding neighbourhoods? Are there a real, healthy and fruitful interconnectedness/ interdependence between the university and its surrounding, particularly most vulnerable, neighbourhoods? And, in the context of this article, can and should the university make a tangible contribution to understandings of homelessness that might inform policy, strategy, practices and investments mediating sustainable alternatives? And can solidarity with issues of homelessness help liberate the university from its own entanglement to neoliberal priorities?

Community engagement and service learning programmes are actively pursued at all universities in South Africa. However, these initiatives often tend to be ad hoc, operating in isolation from each other, scattered all over the city, or characterised by one-way interventions from the university to the community. They often lack sustained and coherent engagement, where mutuality is fostered and genuine sharing of different kinds of knowledge take place. 
Ubuntu-values, if consistently and intentionally practised and embodied by local universities, will have universities struggle with the notion of what it means to be human together. And, through new-found solidarities with homeless challenges in the city, the homelessness of $u b u n t u$ at the university might be subverted and transformed into a recovery of $u b u n t u$-values in its very connectedness to homelessness.

\section{Ubuntu and 'at-home-ness': A recovery}

Ubuntu needs to be embodied concretely in local social contexts. Where we - community workers, faith-based practitioners, activist researchers, local government officials, homeless people, or concerned and caring citizens - engage homelessness together, in solidarity, in order to find new ways of being human together, ubuntu might find expression in concrete ways, as well as a strange new 'at-home-ness'. It is indeed what Cornell et al. (2014:24) call for when they speak of the aspirational nature of ubuntu that call us beyond abstractions and into concrete expressions of shared humanity mediating the public good.

The premise of this article was that $u b u n t u$ is displaced from the mainstream practices and policies governing society, or at its very best $u b u n t u$ is only found as philosophical or political abstractions, and that this is made all the more evident in the precarious situations of street homeless people, landless people and others living in sub-human conditions.

However, at this point it could be asserted that ubuntu is homeless, also in another way. If Jesus was homeless, and if ubuntu is indeed homeless, could it perhaps be argued that it is in the face of homelessness, and our solidarity with those who are homeless or struggling to work for just alternatives to homelessness, that we truly have an opportunity to recover ubuntu, and to recover, amidst the gravest of dehumanised conditions, the possibility of a new and radical humanity? As the humanity of God, Jesus became the humanising one, living amongst a precarious people and mediating human dignity and personhood in almost every situation. The homeless Jesus enters into the deepest of solidarities with a dehumanised humanity, to recover humanity, to restore community. Jesus, and the community Jesus founded, became $u b u n t u$ embodied, even if that community has in its institutional forms mostly strayed from its original vocation.

Examples of the recovery of humanity, overcoming our homelessness and recovering our 'at-home-ness' together, can be found in jurisprudence, in local struggling faith communities, on farms scattered across our national landscape. Drucilla Cornell (in Cornell \& Muvangua 2012:330), for example, says of Justice Albie Sachs: 'the spirit of ubuntu resides in Sachs's jurisprudence', seeking to recover humanness and to overcome homelessness, by being in solidarity with a dehumanised homeless generation.
The struggle to discern what it means to be human together at Central Methodist Mission or in countless other examples of local faith communities becomes a struggle for recovering humanity and 'at-home-ness': it is evoked by the most intense forms of vulnerability, in the eyes and arms of homeless refugees, women, men and children. The attempts of some farmers and farm workers to carve out innovative arrangements in terms of land ownership and profit sharing embody a yearning to embody new ways of being human and 'at home' together: it springs forth from generations of displaced and fractured humanity. And the work being done between people who are homeless and practitioners committed to create systems and nurture practices to overcome homelessness, is evidence of the yearning to be human together.

Recovering $u b u n t u$ in this sense suggests that $u b u n t u$ often only finds us where we dare be in solidarity with the realities of a displaced humanity. We only discover the truest meaning of ubuntu - humanity, humanness - together, in the most dehumanised of situations. In order to find and mediate 'athome-ness' - community, humanity, humanness, ubuntu we who are often comfortably housed are sometimes invited to dwell without a dwelling. To be at home with ourselves, at home in emerging and unfolding African cities, at home with the discrepancies that give birth to strange new transformations, we have to dwell without a dwelling, so that we can become 'at home' together.

To dwell without a dwelling, certainty or any form of security is the kind of reality so familiar, and that in lifethreatening ways, to those who actually call the street their home. To even imply that the experience of emptying ourselves from our often false certainties and securities can bear any resemblance to the physical risk experienced by street homeless people, is to fool oneself. And yet, to dwell without a dwelling is an invitation to those of us committed to imagine a radically different urban society, to be weaned off our certainties and securities, in order to enter into new kinds of solidarities, finding our selves increasingly in the other, in friendships with strangers and people who know the streets as home, embracing a spirituality of the circle.

Joan Chittister (1998:175) speaks of feminist spirituality as that which 'accepts otherness as the palette of creation ...'. It 'embraces the world as part of itself and accepts itself as part of the world, not above it, nor below it, but embedded in the heart of creation'. Chittister (1998:175) considers the biblical text 'I will take out of you your stony hearts and give you hearts of flesh', as an assertion of God's work which is that of making us human again. In Chittister's (1998) language we become human together, with others, in the face of the other, where we are able to embrace a spirituality of the circle, dwelling without dwellings:

I will ... make you human again ... give you a new way of feeling ... thinking ... being ... another chance to live life ... that ennobles you and does not diminish the other ... I will take the 
pyramid of patriarchy and turn it into a circle where, eye to eye and shoulder to shoulder, you may become a creation full of life, full of god-ness. (p. 175)

In the circle of humanity, where we who do not live on the streets connect to our universal deepest forms of homelessness, homelessness/displacement can become the very gift unlocking new and more radical forms of ubuntu, shared humanity, 'at-home-ness'. Then those of us who are the street homeless can help be pathfinders to more meaningful and authentic ways of living and mutuality for all of us, whilst all of us help mediate pathways out of homelessness for those of us who only know the street as home.

\section{Acknowledgements Competing interests}

The author declares that he has no financial or personal relationships which may have inappropriately influenced him in writing this article.

\section{References}

Biko, S., 2008, 'Interview with Gail Gerhart', in A. Mngxitama, A. Alexander \& N.C. Gibson (eds.), Biko lives, p. 34, Palgrave Macmillan, New York.

Chittister, J., 1998, Heart of flesh: Feminist spirituality for women and men, Eerdmans, Grand Rapids, MI.

City of Tshwane, 2013, 'Tshwane homelessness policy', City of Tshwane Metropolitan Municipality, Pretoria.

Cornell, D. \& Muvangua, N., 2012, Ubuntu and the law: African ideals and post apartheid jurisprudence, Fordham University Press, Bronx, NY.

Cornell, D., Van Marle, K. \& Sachs, A., 2014, Albie Sachs and transformation in South Africa: From revolutionary activist to Constitutional Court judge, Birkbeck Law Press, Abingdon, Oxon (UK), New York.

Cross, C., Seager, J., Erasmus, J., Ward, C. \& O'Donovan, M., 2010, 'Skeletons at the feast: A review of street homelessness in South Africa and otherworld regions', Development Southern Africa 27(1), 5-20. http://dx.doi. org/10.1080/03768350903519291

De Beer, S., 2014a, 'Jesus in the dumping sites: Doing theology in the overlaps of human and material waste', HTS Theological Studies/Teologiese Studies 70(3), 1-8. http://dx.doi.org/10.4102/hts.v70i3.2724

De Beer, S., 2014b, Presentation at the launch of the Homeless Summit project, 5 December 2014, Senate Hall, UNISA, Pretoria.

De Beer, S., 2014c, 'Whose knowledges shape our city? Advancing a community based urban praxis', De Jure 47(2), 218-230.

De Beer, S., 2015a, 'Pathways out of homelessness: Research report on street homelessness in the City of Tshwane', unpublished draft/paper, Pretoria.
De Beer, S., 2015b, 'Report on interview with Acting Regional Executive Director and Social Worker of Region 2: City of Tshwane', 01 February, Unpublished.

Duncan, N., 2015, 'Opening presentation at the Tshwane Homeless Summit', unpublished paper, 25 May 2015, Ditsong Museum, Pretoria.

Eze, M.O., 2010, Intellectual history in contemporary South Africa, Palgrave Macmillan, New York.

Gibson, N.C., 2011, Fanonian practices in South Africa: From Steve Biko to Abahlalibase Mjondolo, Palgrave Macmillan, New York/University of Kwazulu-Natal Press.

Hankela, E., 2013, 'Challenging Ubuntu: Open doors and exclusionary boundaries at the Central Methodist Mission in Johannesburg', PhD thesis, Faculty of Theology, University of Helsinki.

Healey, J. \& Sybertz, D., 1996, Towards an African narrative theology, Paulines Publications Africa/Daughters of St Paul, Nairobi.

Jajbhay, M., 2007, City of Johannesburg vs Rand Properties (Pty) Ltd (SCA) 25 at paras. 63-64.

Marx, C., 2002, 'Ubu and Ubuntu: On the dialectics of apartheid and nation building', Politikon 29(1), 49-69. http://dx.doi.org/10.1080/02589340220149434

Mbanjwa, X., 2015, 'Tshwane to raise R 500m in land, property auction', City Press, 21 January.

Ministry of Cooperative Governance and Traditional Affairs, 2014, Integrated Urban Development Framework, Draft 5.1, September 2014.

Mokgoro, Y., 1995, S vs Makwanyane and Another (6) BCLR 665 (CC) at paras. 306-308.

More, M., 2002, 'Nyerere should never have to be marginalised', City Press, 20 October, p. 24.

More, M., 2006, 'South Africa under and after Apartheid', in K. Wiredu (ed.), A companion to African philosophy, pp. 149-160, Blackwell Publishing, Oxford.

Motumi, M., 2014, 'Despair over threat of church eviction', The Star, 29 December.

National Planning Commission, 2011, 'National development plan 2030: Our futureMake it work', viewed 12 June 2014, from http://www.npconline.co.za/MediaLib/ Downloads/Downloads/NDP\%202030\%20-\%200ur\%20future $\% 20-\% 20$ make\%20it\%20work.pdf

Nolan, A., 2006, Jesus today: A spirituality of radical freedom, St. Paul's, Mumbai.

Orobator, A.E., 2008, Theology brewed in an African pot: An introduction to Christian doctrine from an African perspective, Paulines Publications Africa, Nairobi.

Philips, A., 2015, 'Opening presentation at the Tshwane Homeless Summit', Ditsong Museum, Pretoria.

Rahlaga, M., 2014, 'Foreigners evicted from Methodist church', Eyewitness News, 31 December.

Sachs, A., 2005, Port Elizabeth Municipality vs Various Occupiers (1) SA 217 (CC) para. 37.

Sachs, A., 2009, The strange alchemy of life and law, Oxford University Press, Oxford.

Shutte, A., 2001, Ubuntu: An ethic for a new South Africa, Cluster Publications, Pietermaritzburg.

Soja, E., 2000, Postmetropolis: Critical studies of cities and regions, Blackwell Publishing, Oxford.

Terreblanche, S, 2012, Lost in transformation: South Africa's search for a new future since 1986, Kmm Review Pub.

Van Zuydam, L., 2014, 'Spotlight on Pretoria's homeless', Pretoria News, 17 June.

Vellem, V., 2014, 'Life-giving assets at a Johannesburg informal settlement: Black faith and the false gods of multiculturalism in the 21st century', in R.D. Smith, W. Ackah \& A.G. Reddie (eds.), Churches, blackness and contested multiculturalism: Europe, Africa and North America, pp. 207-212, Palgrave Macmillan, New York. 